\title{
BIOCOMPATIBILITY OF ROOT CANAL OBTURATION MATERIALS IMPLANTED IN RATS MUSCULAR TISSUE
}

KARADŽIĆ B and VUJAŠKOVIĆ MIRJANA

Clinic of consevative dentistry and endodontics, School of Dentistry, University of Belgrade, Serbia

(Received 21. October 2008)

The purpose of this study was to investigate the biocompatibility of different dental materials for teeth root canal obturation, implanted in rat muscular tissue, by analyzing the type of muscular tissue inflammatory reaction level.

In the preparation of Wistar rats $M$. biceps femoris, three different materials for root canal obturation were implanted: Sealapex (Kerr, Romulus, USA), AH-26 (DE Trey, Zurich, Switzerland) and Spongio cement material based on polymethil metacrylate - PMMA (Tomić, 1981, US patent 4296209). The used control material was sterile wax.

The rats were sacrificed 30 and 60 days after implantation and the response of the tissue on implanted material was evaluated with standard histological methods on $6 \mu \mathrm{m}$ sections stained with hematoxilin and eosin.

Implantation of Sealapex in rat muscle tissue produced a strong acute inflammation, infiltration with massive polymorphonuclear and numerous giant cells. Acute inflammation still persisted 60 days after implantation.

$A H-26$ produced a strong reaction around the alien body with predominantly limphocitic infiltration. Giant cells and macrophages contained phagocited pieces of material. After 60 days expressive chronic myositis was present with a mass of giant cells and proliferation of connective tissue.

Thirty days later the results of histological investigations suggested that implanted PMMA based material still produced a connective fibrous capsula made of fibroblasts and fibrocytes around the implanted material. In the muscular tissue myositis developed forming granulomatous tissue. After 60 days a capsula was made of mature hyalinisated connective tissue without signs of inflammation in the surrounding muscular tissue. The reaction is similar to the reaction to inert control material, such as sterile wax. These findings suggest biocompatibility of PMMA based material for canal obturation.

Key words: biocompatibility, muscular tissue, rat, root canal obturation, root canal sealer 


\section{INTRODUCTION}

Biocompatibility is defined as the ability of a material to function in a specific application in the presence of the appropriate host's response.

Biocompatibility of endodontic materials is characterized by many parameters such as: genotoxicity, mutagenicity, carcinogenicity, citotoxicity, histocompatibility and microbial effects. The research of newly developed materials with different mathods starts from a simple to the most complicated testing methods, from in vitro to animal testing and from preclinical to clinical testing on humans (Hauman and Love, 2003).

Implantation test is a nonspecific in vivo test of the tissue response to endodontic materials which is normally done with histological examination during analysis of the tested materials implanted into various animal tissues. Test materials could be directly injected or implanted by means of Teflon, silicone or polyethylene tubes into various tissues, muscle or bone of rats, rabbits, guinea pigs etc. (Hauman and Love, 2003).

Research of dental materials biocompatibility is mainly based on citotoxicity, Ideally, root canal sealers should be nontoxic and nonirritant for the surrounding tissues (Hauman and Love, 2003; Bernath and Szabo, 2003; Huang et al., 2002).

Materials for root canal obturation contain different chemical substances which may cause tissue irritation and inflammation. Tissue reaction on released substances depends on the amount and time of resorption. Freshly mixed material samples release the highest amount of toxic substances. The release of detrimental components is constant in tissue fluid producing less or more citotoxic reactions during longer or shorter periods of time (Hauman and Love, 2003).

Zinc oxide eugenole based obturation pastes release eugenol (Torabinejad et al., 1984; Gulati et al., 1991; Leonardo et al., 1998). Epoxi resin based materials contain hexamethylenetetramine (methenamine) as catalyst / disinfectant agent and release formaldehyde after setting (Guertsen and Leyhausen, 1997; DiFelice et al., 1998).

However, there is a lack of knowledge on metacrylate based endodontic materials. Cyano-acrilic cements (McComb and Smith, 1976; Torabinejad et al., 1984; Barkhordar et al., 1988; Smith and Smith, 1993), Poly-HEMA (Hydron, NPD dental systems INC, New Brunchwire, NY) - (Weine, 1989) and bone cements PMMA based (Heeley and Tomic, 1981; Linden et al., 1981; Karadzic 1999, 2001, 2004) and PEMA - polyethil metacrylate (Ahlberg and Tay, 1996), are materials for root canal obturation, which showed high tolerancy to human periapical tissue. In this study we used Spongio cement (Tomić, 1981, US patent 4296209) PMMA based (Palacos) used in Ortopedic surgery for hip protesis cementation and reconstruction of bone defects. The aim of this study was to determine the inflammatory reaction level of muscle tissue of laboratory rats on implanted materials for final rooth canal obturation: $\mathrm{AH}-26$ and Sealapex daily used in dental surgery and PMMA Spongio cement based materials. 
Acta Veterinaria (Beograd), Vol. 59. No. 2-3, 267-276, 2009.

\section{MATERIAL AND METHODS}

Experimental animals

Histopatological research of material for root canal obturation biocompatibility included 24 Wistar homozigote rats, masculine gender, 360 to 520 grams body weight, divaded into four groups.

\section{Material and methods}

AH-26 (DeTrey, Zurich, Switzerland), Sealapex (Kerr, Romulus, USA) PMMA Spongio cement based materials (Tomic 1981, US patent 4296209), and control sterile wax were implanted in prepared rat's $m$. biceps femoris. The animals were divided into four groups.

Each group contained four animals and the research period was 30 and 60 days.

\section{Experimental procedure}

The animals were given intraperitoneal anesthesia with $5 \mathrm{mg} / 100 \mathrm{~g} \mathrm{BW}$ of Nesdonal on $100 \mathrm{gr}$. of body weight. The surgical site on rats back leg was swabbed and disinfected with iodine solution. The skin was shaved and a $3 \mathrm{~mm}$ long incision was done with a surgical blade. A pocket was made in $m$. biceps femoris and the material was immediately implanted into the pocket. The skin was then sutured.

\section{Histological procedure}

The rats were sacrificed 30 and 60 days after implantation and a part of $m$. biceps femoris was incised and immidietaly fixed in $7 \%$ formalin for 24 hours. After fixation the tissue blocks were prepared for histological examination and embedded in paraffin for sectioning at a thickness of $6 \mu \mathrm{m}$. The sections were mounted on glass slides and stained with Mayer haematoxillin and eosin.

The type and size of inflammatory muscle tissue reaction in contact with the implanted dental material was studied from images taken with Olympus $\mathrm{AH}-2$ microscope.

\section{RESULTS}

Sealapex implanted in rat muscle tissue produced acute inflammation with abscessed formations around the material, with massive polymorphonuclear production, granulocyte infiltration with numerous multinuclear giants cells foreign body type. Acute inflammation still existed 60 days after implantation.

The life time of these cells is very short because of calcium distrofies in the capsula forming zones. Oval and circular violet zones were clearly seen on the photographs.

Infiltration intensity from the central zone to the periphery decreases, thus changing the cellular structure. There are numerous mononuclear cells, small and big lymphocytes and plasmocytes. 


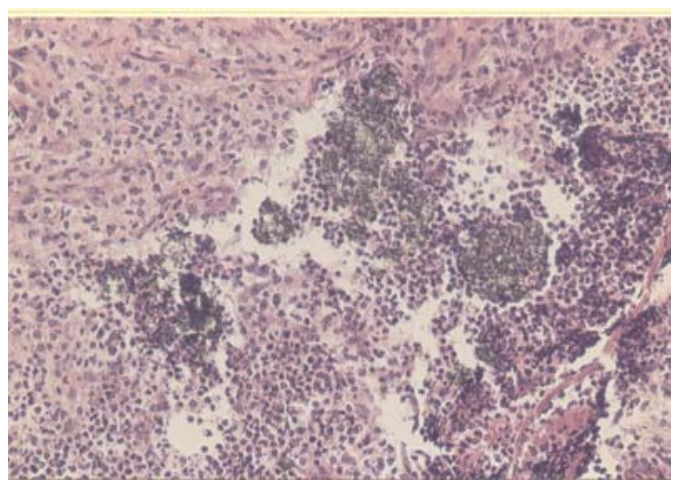

Figure 1. Excessive acute inflammation with predominant neutrophyl granulocytes around Sealapex (black granules) (Formol, HE, 211x)
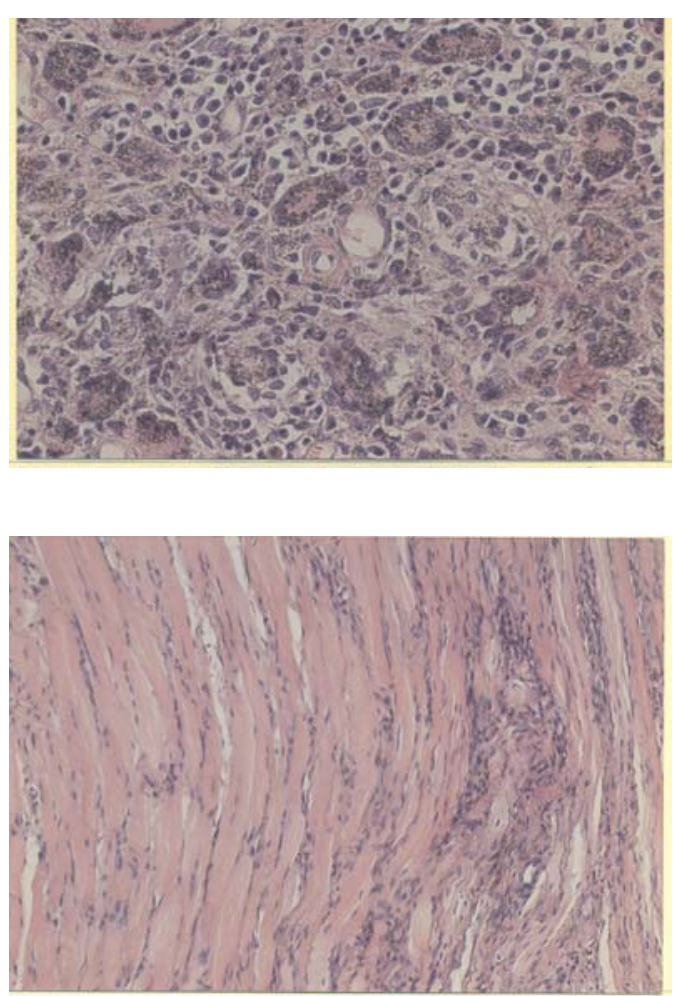

Figure 2. Strong acute inflammation around Sealapex 60 days after implantation with numerous macrophages and giant cells. Connective tissue was multiplied, but in the mixed infiltrate predominated mononuclear cells (Formol, HE, 212x)

Figure 3. Chronic miositis with proliferation of connective fibers in the perimisium with a predominant lymphocytic infiltration (Formol, HE, 128x)

$\mathrm{AH}-26$ produces a severe inflammatory reaction in rat muscular tissue around the foreign body, as well as an acute inflammation infiltration (neuthrophilic granulocytes).

Spongio cement produced a small chronic miositis with proliferation of connective tissue, lacking multinuclear giant cells. 
Acta Veterinaria (Beograd), Vol. 59. No. 2-3, 267-276, 2009.

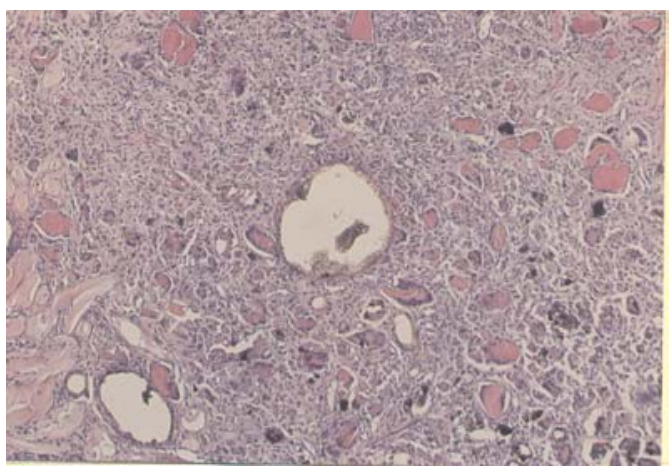

Figure 4. Myositis with numerous giant cells with phagocyted black material. Connective tissue proliferate, cystic formations filled with gray-gold material can be seen (Formol, HE, 80x)

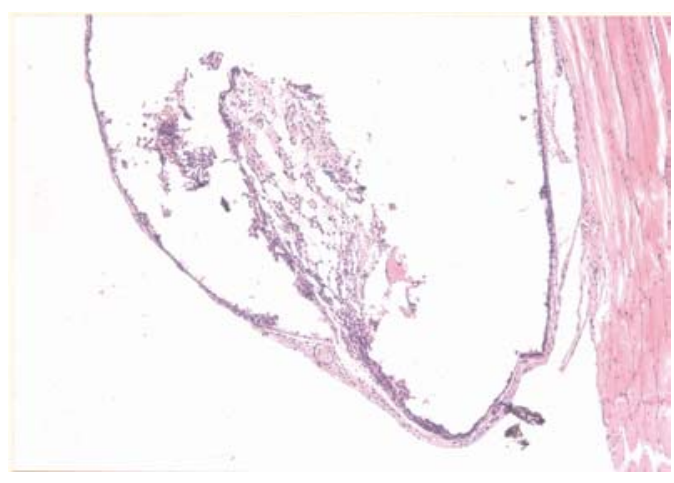

Figure 5. Connective tissue capsula is formed around the material of fibroblasts and fibrocytes. Chronic myositis is present, with granulated tissue and signs of acute inflammation (Formol, HE, 51x)

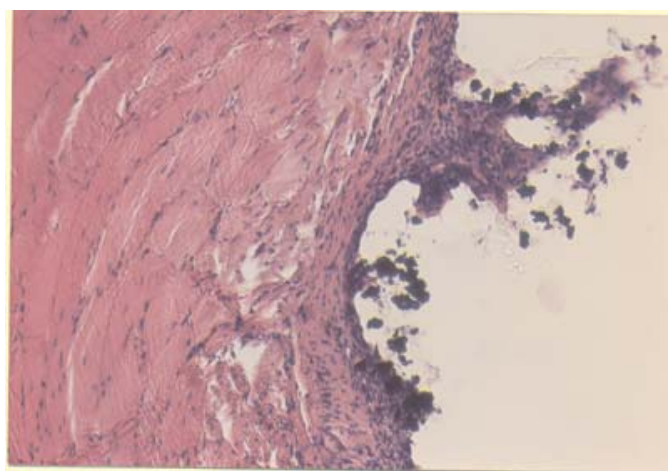

Figure 6. 60 days after implantation the connective capsula was formed in the deeper layers, made of young fibroblasts and fibrocites. Besides muscular tissue there is hyalinized connective tissue. The surrounding muscular tissue is without signs of inflammation

(Formol, HE, 128x)

Connective (fibrous) tissue capsula around the material was predominantly made of mature cells and mature hyalinized collagene fibres with a minimal inflammatory reaction.

The control material which consisted of indifferent sterile wax, produced a reaction similar to Spongio cement. There was a mature fibrous capsula 
surrounding the material in contrast to the severe acute reaction produced by the alien body (anorganic surgical suture).

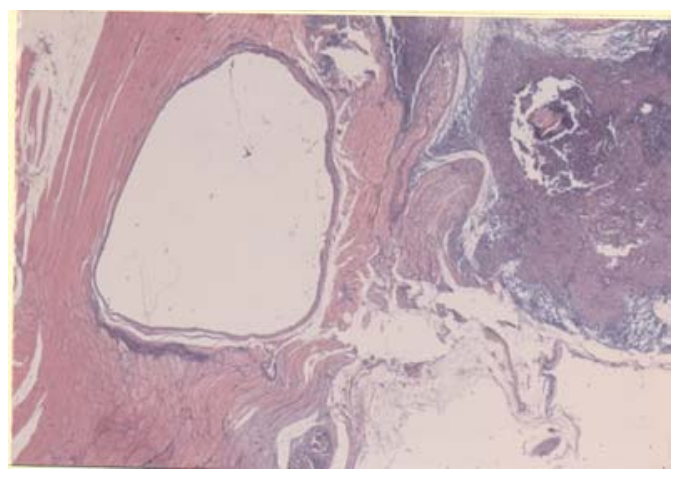

Figure 7. Cystic formation encircled by a connective tissue capsula, surrounding the sterile wax with a weak inflammatory reaction in the muscular tissue

(Formol, HE, 16x)

\section{DISCUSSION}

In this study the observed animals were WISTAR rats (Hashieh et al., 1999), which are usually used for testing biocompatibility, due to the great similarity of muscular tissue histological structure of humans and rats (Heeley and Tomic, 1981; Linden et al., 1981; Vujasković, 1999; Karadzic, 1999, 2001, 2004; Markovic et al., 2006).

Biocompatibillity testing of endodontic materials for root canal obturation in this study represents a nonspecific study of in vivo citotoxicity, as a secondary test (ISO, 1984, Tehnical report 7450) of implantation materials in the muscular tissue of tested animals (Hauman and Love, 2003).

The research period (30 and 60 days) was taken to be so long in order to avoid early acute reactions after tissue preparation and the application of the material itself.

It is known that the tissue reacts on trauma during material application, with a nonspecific acute inflammatory reaction and tissue necrosis. After a certain period of time the organism responds to the implanted material with a specific reaction, which depends on material composition and the time of setting (Schroder, 1985; Leonardo et al., 1997; Leonardo et al., 1998).

$\mathrm{AH}-26$ paste produced a severe inflammatory reaction in the muscular tissue, even after the studied period of 30 and 60 days from implantation.

Cystic formations around the material surrounded by connective tissue is the sign of chemical and mechanical irritation, excluding infection as the cause of inflammation. This incapsulation is the sign of limitation of the alien material in the tissue. Epoxy bisfenolic resin and hexamethylenetetramine (methenamine) from the $\mathrm{AH}-26$ paste, which is hydrolysed to ammonia and formaldehyde showed the highest release in freshly mixed samples and decreased after setting (Smith and Smith, 1968; Spangberg et al., 1993; DiFelice and Lombardi, 1998; Bernath and Szabo, 2003; Human and Love, 2003; Kaplan et al., 2003). 
The release of many multinuclear giant cells with fagocited particules of material showed tissue activity to eliminate irritative elements of alien material (Geurtsen and Leyhausen, 1997; Markovic et al., 2006; Schroder, 1985).

Such tissue response was expected in our study, as many authors have shown similar or same results on experimental animal tissue on implanted sealers based on epoxy resins (Smith and Smith, 1968; Alvas, 1982; Barkhordar et al., 1988; DiFelice and Lombardi, 1998; Ahlberg and Tay, 1996; Vujasković, 1999; Bernath and Szabo, 2003).

Sealapex implantation in rat muscular tissue showed severe chronic myosotis, with proliferation of connective tissue which was incapsulated by the material. Such severe reactions of muscle tissue could be explained by the alkalinity of the material during the long period because of insolubility or slow solubility of calcium hydroxide in tissue fluids (Schroder, 1985; Trondstad and Barnett, 1988; Hauman and Love, 2003). Some authors have shown an intensive and strong inflammatory response to the material in the early phase and a moderate reaction later on (Leonardo et al., 1998; Huang et al., 2002; Bernath and Szabo, 2003; Hauman and Love, 2003).

Most of them have shown low citotoxicity of calcium hydroxide based materials (Zmener, 1981; Barkhordar et al., 1988; Matsumoto et al., 1989; Weine, 1989; Takahara et al., 1990; Leinenbach et al., 1993; Spangberg et al., 1993; Mittal et al., 1995; Vairabhaya et al., 1997; DiFelice and Lombardi, 1998; Leonardo et al., 1999; Bernath and Szabo, 2003; Hauman and Love, 2003), which our study does not support.

Analizing the results of muscular tissue reaction on implanted PMMA Spongio cement based material, we found a low level hronic inflammation around the capsula formed of mature connective tissue only 30 days after implantation. After 60 days, the capsula was completely made of hyalinizated collagen fibres and mature cells. The reaction is minimal in the surrounding tissue with rare giant cells.

Relative indifference of materials was proved in the studies of Linden et al. (1981) Helley and Tomic (1981) as well as Alvas (1982) with the reaction being milder then on pure PMMA because of the positive effect of $\mathrm{Ca}(\mathrm{CO})_{3}$ and $\mathrm{Na}_{2} \mathrm{HPO}_{4}$ added.

Smith and Smith (1968), Zmener (1981), McComb and Smith (1976) definitly opturated root canals with cyan acrylic cement, without visible toxic effects on the periapical tissue. Torabinejad et al. (1984), Barkhordar et al. (1988), recommended cyano acrylic cements for canal and retrograde root canal obturation.

Beside cyanoacrylate cements, poly-HEMA as a hydrofilic gel (poly-2hidroxy etyl metacrylate) did not produce any toxic effects on the periapical tissue, when the material passed through the apical foramen (Weine, 1989). Ahlberg and Tay (1996), using polyethyl metacrylate (PEMA) for root canal obturation, pointed to its hystocompatibility and osteoconductivity and its support to the reparation of periapical tissue lessions. Karadžić (1999) used Spongio cement in the therapy of periapical lessions, placing over the material above the apical foramen. The therapy was succesfull in more than $90 \%$ cases. 


\section{CONCLUSION}

Implantation of Sealapex in rat muscular tissue produced severe acute inflammatory reactions with a massive infiltration of polymorphonuclears and numerous giant cells.

AH-26 paste produced a strong foreign body reaction with lymphocyte predominance. Giant cells and macrophages contained fagocyted particles of the material. 60 days after implantation we found severe chronic myositis with a mass of giant cells and proliferated connective tissue.

AH-26 and Sealapex materials for root canal obturation showed citotoxic effects when implanted in the muscular tissue of rats.

The results of histological examinations of PMMA based implantation material, showed a formation of fibrous connective capsula made of fybroblasts and fybrocytes surrounding the material only after 30 days.

After 60 days a capsula was formed of mature hyalinizated connective tissue, without any signs of inflammation. The reaction is similar to the reaction to the control material (inert sterile wax). These findings point to the relative indifference of the biocompatibility of PMMA based materials.

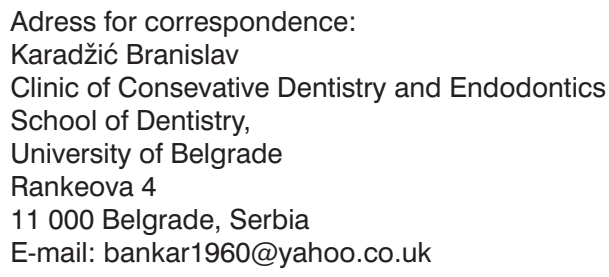

\section{REFERENCES}

1. Ahlberg KMF, Tay WM, 1996, A Metacrylate Based Cement Used As A Root Canal Sealer, Int Ednod $J, 31,15-21$.

2. Alvas J, 1982, Comparison of Selected Alloplast And Allograft Materials Utilized for Repair of Arteficially Created Alveolar Bone Defect In Dogs, PhD Thesis, Faculty of Medicine Harvard University, dept. of Histology and Histochemistry, Forsyth Institute for research and advanced study in Dentistry.

3. Barkhordar RA, Javid B, Abbasi J, Watanabe LG, 1988, Cyanoacrylate As A Retro Filling Material, Oral Surg Oral Med Oral Pat, 65, 468-73.

4. Bernath M, Szabo J, 2003, Tissue reaction initiated by different sealers Int Endod J, 36, 4, $256-61$.

5. Di Felice R, Lombardi T, 1998, Gingival and mandibular bone necrosis caused by a paraformaldehyde containing past, Endodont Dent Traumatol 14, $196-8$.

6. Geurtsen W, Leyhausen GB, 1997, Biological aspects of root canal filling materials. Histocompatibility, citotoxicity and mutagenicity, Clin Oral invastig, 1, 5-11.

7. Gulati N, Chandra S, Aggarwal PK, Kaiswal JN, Singh M, 1991, Citotoxity of eugenol in sealer containing zinc oxide, Endodont Dent Traumatol, 7, 181-5.

8. Hashieh IA, Pommel L, Camps J, 1999, Concentration of eugenol apically released from zinc oxide eugenol based sealers, $J$ Endod, 25, 713-5.

9. Hauman CHJ, Love RM, 2003, Biocompatibility of dental materials used in contemporary endodontic therapy: a review. Part 1. Intracanal drugs and substances, Int Endod J, 36, 75-85. 
10. Hauman CHJ, Love RM, 2003, Biocompatibility of dental materials used in contemporary endodontic therapy: a review. Part 2. Root canal-filling materials, Int Endod J, 36, 147-60.

11. Huang FM, Tai KW, Chou MY, Chang YC, 2002, Cytotoxycity of resin-zinc oxide-eugenol, and calcium hidroxide-based root canal sealers on human periodontal ligament cells and permanent V79 cells, Int Endod J, 35, 153-8.

12. Heeley JD, Tomić D, 1981, Histocompatibility of Subcutaneously Implanted Bone Cement in Rats J Dent Research, Vol. 60, abstracts $59^{\text {th }}$ General Session and Annual Session of IADR and AADR, Chicago, llinois.

13. Kaplan AE, Ormaechea MF, Picca M, Canzobre MC, Ubios AM, 2003, Rheological properties and bicompatibility of endodontic sealers, Int Endod J, 36 , 527-32.

14. Karadžić $B$, 1999, Primena polimetil metakrilata u endodontskoj terapiji hroničnih apeksnih parodontita, PhD Thesis, University of Belgrade, School of Dentistry.

15. Karadžić B, 2004, Ispitivanje biokompatibilnosti materijala na bazi PMMA implantiranih u koštano tkivo, Serbian Dent J, 51, 183-7.

16. Karadžić B, Bojovic S, 2001, Rat muscle tissue response on implanted matherials for canal obturation, Abstracts, $6^{\text {th }}$ Congres of the Balcan Stomatological society, Bucharest.

17. Leinenbach F, Leychausen G, Geurtsen W, 1993, Biocompatibility of root canal filling materials in fibroblast cultures (abst.), J Dent Res, 72, 219

18. Leonardo MR, da Silva LAB, Filho MT, da Silva RS, 1999, Release of formaldehyde by 4 endodontic sealers, Oral Surg Oral Med Oral Path Oral Radiol Endod, 88, 221-5.

19. Leonardo MR, da Silva LA, Utrilla LS, Assed S, Ether SS, 1997, Calcium hydroxide root canal sealers-histopathologic evaluation of apical and periapical repair after endodontic treatment, $J$ of Endod, 23, 428-32

20. Leonardo MR, Ameida WA, Da Silva LA, Utrilla LS, 1998, Histological evaluation of the response of apical tissues to glass ionomer and zinc oxide based sealers in dog teeth after root canal treatment. Endodont Dent Traumatol, 14, 257-61.

21. Linden JW, Heeley JD, Tomić D, 1981, Biocompatibility of A New Root Canal Filling Material In Rat Periapical Tissue J Dent Research, Vol. 60, abstracts $59^{\text {th }}$ General Session and Annual Session of IADR and AADR, Chicago, Ilinois, 1981.

22. Matsumoto K, Inoue K, Matsumoto A, 1989, The Effect Of Newely Developed Root Canal Sealers On A Rat Dental Pulp Cells In Primary Culture, J of Endod, 15, 60-7.

23. Marković D, Zivojinovic V, Jokanovic Krstic V, 2006, Biocompatibility of nano structured carbonated calcium hydroxiapatite obtained by hydrothermal method, Acta Vet Beograd, 56, 5-6, 541- 51

24. Mc Comb D, Smith DC, 1976, Compatation Of Physical Properties Of Polycarboxylate Based And Conventional Root Canal Sealers, J Endodon, 2, 228-35

25. Mittal M, Chandra S, Chandra Sh, 1995, Comparative Tissue Toxity Evaluation Of Four Endodontic Sealers, J Endod, 12, 622-4

26. Mjör IA, Dental Materials, 1985, Biological Properties And Clinical Evaluations, CRC Press Inc. Boca Raton, Florida.

27. Pascon EA, Leonardo MR, Safaci K, Langeland K, 1991, Tissue reaction to endodontic matherials: methods, criteria, assessment and observations, Oral Surg Oral Med Oral Pat, 72, 222-37.

28. Schroder U, 1985, Effect Of Calcium Hydroxyde Containing Pulp Cupping Agens Of Pulp Cell Migration Proliferation And Differentiation, J Dent Res, 64, 541-8.

29. Smith ZZ, Smith DC, 1968, A New Dental Cement, Br Dent J, 124, 381-4

30. Spangberg J, Barbosa SV, Lavigne GD, 1993, AH-26 releases formaldehyde, J Endod, 596-7, 1993.

31. Takahara K, Onodera A, Matsumoto K, 1990, Toxity of root canal sealers on rat bone cells in primary culture, Endod Dent Traumatol, 6, 200-7.

32. Torabinejad M, Kahn H, Bankes D, 1984, Isporopil Cyanoacrylate As A Root Canal Sealer, J Endod, 10, 304-7.

33. Trondstad I, Barnett E, Flax M, 1988, Solubility and biocompatibility of calcium hydroxide containing root canal sealers. Endodont Dental Traumatol, 4, 152-9. 
34. Vairabhaya L, Sithisarn P, Wilairat P, Leelaphiwat S, 1997, Comparison Between Sulphorhodamine-B Dye Staining And ${ }^{51}$ CR-released Method In Citotoxity Assay Of Endodontics Sealers, J Endod, 23, 355-7.

35. Vujašković $M, 1999$, Biofizičke osobine glas jonomer cemenata kao sredstava za opturaciju kanala korena u poređenju sa standardnim materijalima, PhD Thesis, University of Belgrade, School of Dentistry.

36. Weine FS, 1989, Enndodontic Therapy $4^{\text {th }}$ edition. The CV Mosby Co, St Louis, Baltimore, Toronto, 1989.

37. Zmener O, 1981, Evaluation Of The Apical Seal Obtained With Endodotnic Implant Stabilizers And Different Cementing Materials, Oral Surg, 52, 635-40.

\title{
ISPITIVANJE BIOKOMPATIBILNOSTI DENTALNIH MATERIJALA ZA PUNJENJE KANALA KORENA IMPLANTIRANIH U MIŠIĆNO TKIVO PACOVA
}

\author{
KARADŽIĆ B i VUJAŠKOVIĆ MIRJANA
}

\section{SADRŽAJ}

Cilj ovog rada je bio da se, na osnovu analize tipa i stepena inflamatorne reakcije koje izazivaju različiti materijali za punjenje kanala korena zuba - sileri, ispita njihova biokompatibilnost nakon unošenja u mišićno tkivo pacova.

U poprečno presečen $m$. biceps femoris laboratorijskih pacova Wistar soja inplantirane su paste za opturaciju kanala Sealapex (Kerr, Romulus, USA), AH 26 (DE Trey, Zurich, Switzerland) i Spongio cement preparat na bazi PMMA (Tomić, 1981, US patent 4296209), a kao kontrolni materijal stomatološki roze vosak. Životinje su bile žrtvovane nakon 30 i 60 dana, a materijal je pripreman za patohistološke pretrage standardnom tehnikom i bojen hematoksilin eozinom.

Spongio cement u mišićnom tkivu oko implantiranog materijala daje hronično zapaljenje, uz stvaranje vezivne kapsule sagrađene od fibroblasta i fibrocita. Nakon 60 dana, kapsula je sagrađena od zrelih ćelija i hijeliniziranih kolagenih vlakana. Implantacija Sealapexa u mišićno tkivo pacova, produkuje jaku hroničnu inflamaciju sa masivnom infiltracijom polimorfonukleara i džinovskih ćelija, koja postoji i nakon 60 dana od implantacije.

Pasta AH-26 izaziva burnu reakciju mišićnog tkiva na strano telo sa izraženom limfocitarnom infiltracijom. Nakon 60 dana, prisutna je hronična inflamacija uz prisustvo brojnih džinovskih ćelija i makrofaga koje sadrže fagocitovane deliće materijala, dok vezivno tkivo proliferiše uz stvaranje cističnih tvorevina. 